\title{
Peak sea level during the warm Pliocene: Errors, limitations, and constraints
}

\author{
Kenneth G. Miller ${ }^{1}$, M.E. Raymo², J.V. Browning ${ }^{1}$, Y. Rosenthal' ${ }^{1}$ and J.D. Wright ${ }^{1}$
}

\begin{abstract}
Re-evaluation of Pliocene sea levels indicates large errors (up to $\pm 15 \mathrm{~m}$ ), precluding firm estimates. Sea level appears to have peaked at 10-20 m above present, consistent with some ice loss from the East Antarctic ice sheet (EAIS) as suggested by models and Antarctic sediments. More accurate estimates of Pliocene peak sea level require improved modeling techniques and proxy evaluation.
\end{abstract}

The Pliocene recorded a period of global warmth and high sea level that can provide constraints on relationships among global climate, atmospheric $\mathrm{CO}_{2}$, and sea-level changes (Raymo et al. 2009, 2011; Miller et al. 2012). Global surface temperatures during the most recent period of Pliocene warmth at ca. $3 \mathrm{Ma}$ were $2-3^{\circ} \mathrm{C}$ warmer than the 20th century (Dowsett et al. 2013). Pliocene atmospheric $\mathrm{CO}_{2}$ estimates of $400 \pm 25 \mathrm{ppmv}$ (e.g. Bartoli et al. 2011) are similar to those observed today.

Published estimates of the peak Pliocene sea level span a wide range, though a peak of $25 \mathrm{~m}$ is often cited (e.g. Dowsett et al. 2013). Miller et al. (2012) estimated a peak of $22 \pm 10 \mathrm{~m}$ by comparing continental margin (Wanganui Basin, New Zealand; VA, USA), atoll (Enewetak), and deep-sea benthic foraminiferal $\delta^{18} \mathrm{O}\left(\delta^{18} \mathrm{O}_{\text {benthic }}\right)$ and $\mathrm{Mg} / \mathrm{Ca}$ records. More recent work has shown that much of the variance among continental records can be attributed to regional changes in mantle dynamic topography (MDT) and glacial isostatic adjustment (GIA) (e.g. Raymo et al. 2011) and that estimates derived from continental sections have large errors of $\pm 10 \mathrm{~m}$ or larger due to these effects (Rovere et al. 2014). Deep-sea $\delta^{18} \mathrm{O}_{\text {benthic }}$ and $\mathrm{Mg} / \mathrm{Ca}$ records potentially provide a means of independently estimating ice volume, and hence global mean sea level (GMSL) variations. For example, Woodard et al. (2014) used $\delta^{18} \mathrm{O}_{\text {benthic }}$ and $\mathrm{Mg} / \mathrm{Ca}$ records to provide estimates of the Pliocene peak of $21 \pm 10 \mathrm{~m}$. However, Raymo et al. (2018) provided extensive discussion of errors on $\delta^{18} \mathrm{O}_{\text {benthic }}-\mathrm{Mg} / \mathrm{Ca}$ method, showing that they are potentially quite large $( \pm 15 \mathrm{~m}$ or larger) due to diagenesis and changing ocean chemistry over millions of years. These are critical areas for future study and advancement.

\section{Measuring sea level relative \\ to the continents}

Continental margins contain a record of over a billion years of sea-level change, though the water depth changes observed as transgressions and regressions reflect many processes including GMSL (eustasy), subsidence/uplift (including MDT), and sediment input/loading. "Backstripping" is a method that progressively removes the effects of compaction, loading, and thermal subsidence from water-depth changes, with the residual reflecting the effects of GMSL and non-thermal tectonism (e.g. Kominz et al. 2016), including changes in MDT.

Using the backstripping technique, it is pos sible to quantify Pliocene differential movement between Virginia (VA) and New Jersey (NJ; Fig. 1). Both records are similar in the Miocene until 7.5 Myr BP when a hiatus is observed in NJ cores. Backstripping of water depth variations suggests at least $\sim 20 \mathrm{~m}$ of differential movement between VA and NJ (Fig. 1). We attribute the difference between VA and NJ to MDT, as suggested by modeling by Rowley et al. (2013). In the absence of other datasets, it would be impossible to tell if VA subsided or if NJ was uplifted (Fig. 1), calling into question the estimates of $17 \pm 10$ $\mathrm{m}$ obtained from the VA records (e.g. Miller et al. 2012).

A new $\delta^{18} \mathrm{O}-\mathrm{Mg} / \mathrm{Ca}$ based sea-level record Previous Pliocene studies used $\delta^{18} \mathrm{O}$ as a sea-level proxy and relied on the Lisiecki and Raymo (2005; hereafter LR04) benthic foraminiferal $\delta^{18} \mathrm{O}$ stack (Miller et al. 2011) or Atlantic $\delta^{18} \mathrm{O}$ and $\mathrm{Mg} / \mathrm{Ca}$ records overprinted by North Atlantic circulation effects (e.g. Woodard et al. 2014). The LR04 stack incorporates Atlantic and Pacific records though it is weighted toward Atlantic records. LR04 provides a pristine chronology, but like any stack, it shows a reduction in the amplitude of $\delta^{18} \mathrm{O}_{\text {benthic }}$ signal caused by combining records.

Pacific $\delta^{18} \mathrm{O}_{\text {benthic }}$ changes reflect variations in deep-water temperature and $\delta^{18} \mathrm{O}_{\text {se }}$ they are less affected by regional circulation and other changes because the Pacific comprises $60 \%$ of the global ocean reservoir. Differences in Pacific $\delta^{18} \mathrm{O}_{\text {benthic }}$ values between the peak Pliocene values and modern values provide a constraint on high sea-level estimates. The relatively minor difference in $\delta^{18} \mathrm{O}_{\text {benthic }}$ between the modern and Pliocene in the LR04 stack may possibly be attributed to various biases and not accurately scale to the difference in ice volume (Raymo et al. 2018). Still, Pacific $\delta^{18} O_{\text {benthic }}$ values can place

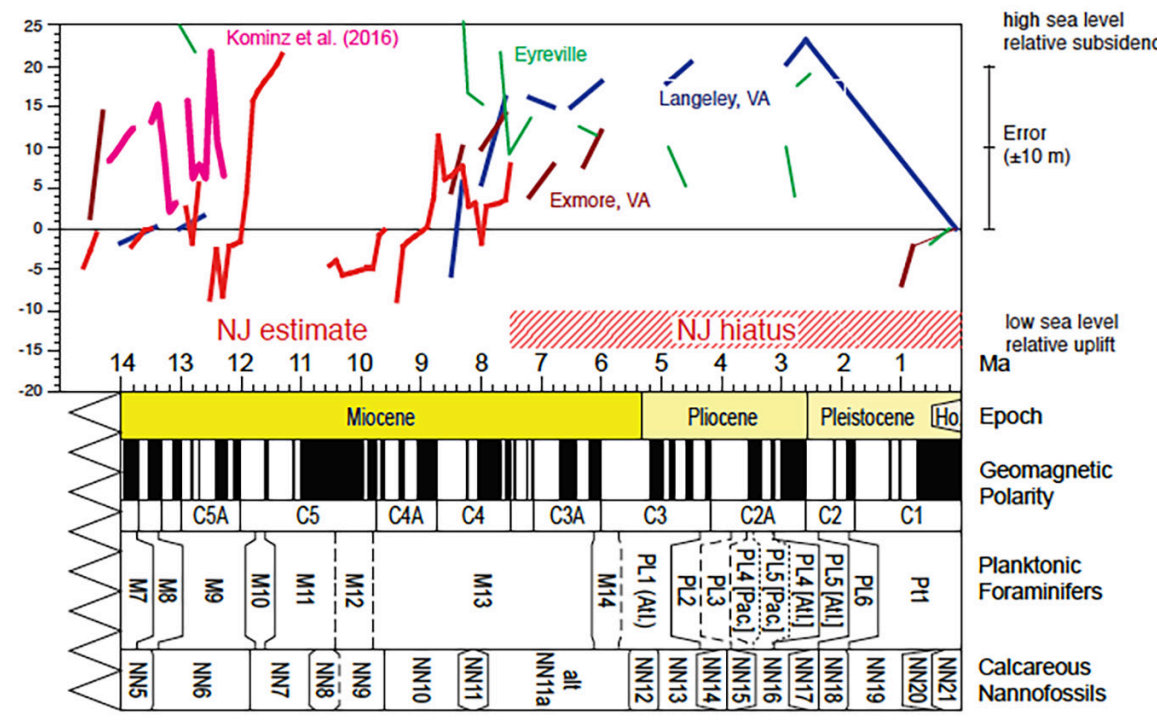

Figure 1: Relative sea level from the US east coast. This figure illustrates differential movement between VA and NJ during the Late Miocene to Pliocene due to MDT as modeled by Rowley et al. (2013). Shown are NJ backstripped estimates (red = Miller et al. 2005; magenta $=$ Kominz et al. 2016), and VA estimates (blue = Langley, purple = Exmore, both after Hayden et al. 2008; green = Exmore after Miller et al. 2012). The marine Miocene section in NJ is replaced by Pliocene upland gravels in outcrop deposited above sea level indicating relative uplift in $\mathrm{NJ}$. 


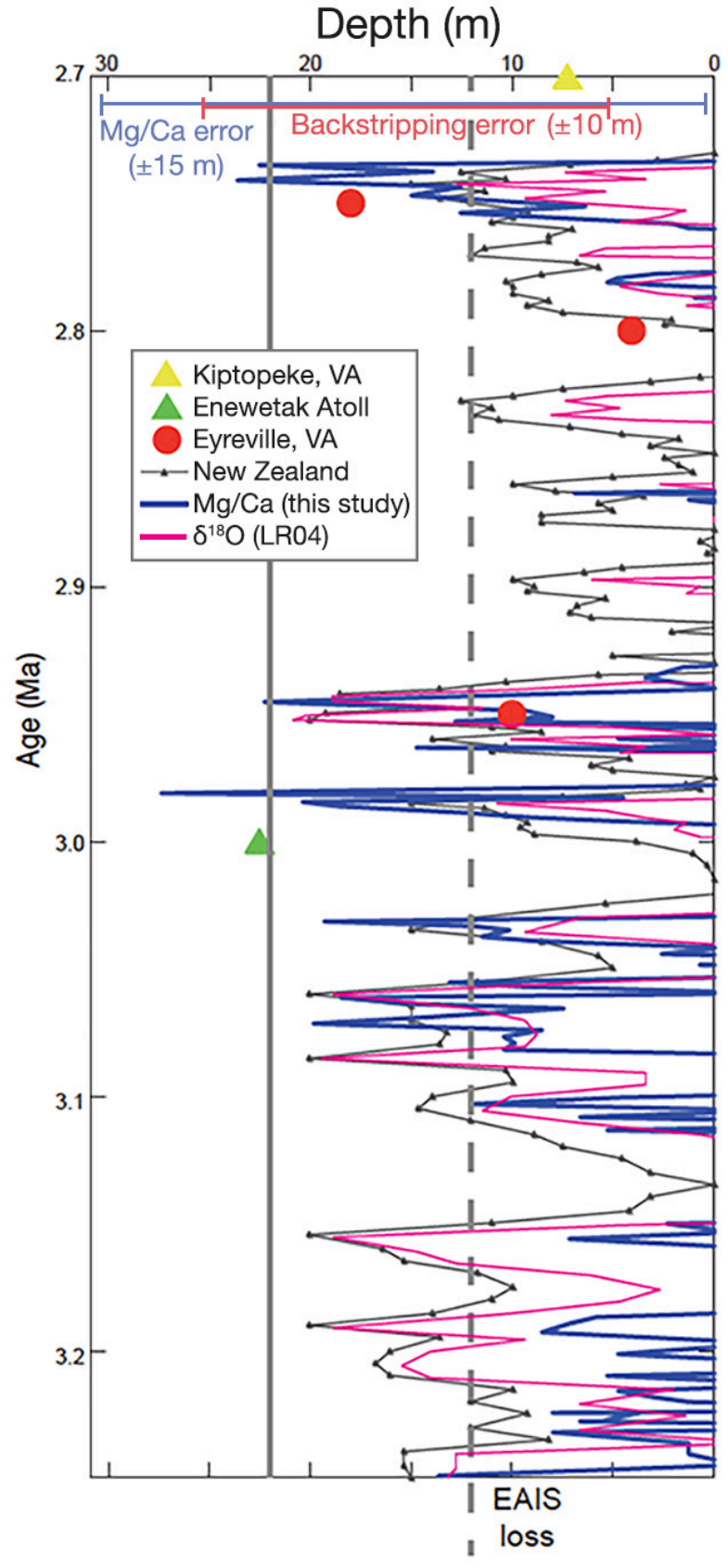

Figure 2: $\delta^{18} \mathrm{O}-\mathrm{Mg} / \mathrm{Ca}$ based sea-level estimate updated from Miller et al. (2012). Map shows Exmore (E) Kiptopeke (K) and Langley (L) coreholes and Wanganui Basin (W). Sea levels to the left of the dashed vertical line suggest some melting of the EIAS.

constraints on sea level during the mid-Pliocene warm extremes.

Here, we use the best-resolved Pacific benthic foraminiferal (Uvigerina) record compiled from Pacific Site 846 ( $3^{\circ} 06^{\prime} S_{\text {, }}$ 9049'W, 3307 m water depth; data compiled and astronomically dated by Lisiecki and Raymo 2005; lorraine-lisiecki. $\mathrm{com} /$ stack.html). At Site 846, the difference between peak Pliocene $\delta^{18} \mathrm{O}_{\text {benthic }}$ values and modern is $\sim 0.63 \%$, similar to the $0.5 \%$ difference observed at Pacific Site 1208 (3346 m water depth; Woodard et al. 2014), but significantly larger than observed in the LR04 stack $(0.3 \%$ ). Pacific deep-water temperatures during Pliocene interglacials were warmer than present $\left(\sim 1.5 \pm 0.5^{\circ} \mathrm{C}\right.$ warmer from $\mathrm{Mg} / \mathrm{Ca}$; Woodard et al. 2014), suggesting that only $0.13-0.25 \%$ of the $\delta^{18} \mathrm{O}_{\text {benthic }}$ signal can be attributed to $\delta^{18} \mathrm{O}_{\text {seawater }}$ and $10-20 \mathrm{~m}$ higher sea levels due to melting of ice sheets. Values less than 10 $\mathrm{m}$ can also be excluded by our intuition that sea level in the Pliocene was higher than the last major interglacial (Marine Isotope Stage 5 e that has a GMSL $8 \pm 2 \mathrm{~m}$ above present; Dutton et al. 2015) due to the enhanced Pliocene global warmth.

We use the Site $846 \delta^{18} \mathrm{O}_{\text {benthic }}$ record to provide a new sea-level curve following the approach of Cramer et al. (2011), assuming Milankovitch scale (104-105 year) temperature changes comprise $\sim 20 \%$ of the $\delta^{18} \mathrm{O}_{\text {benthic }}$ changes, and the $\delta^{18} \mathrm{O}_{\text {seawater }}$-sealevel calibration of 0.13\%/10 m (Winnick and Caves 2015). Comparison of the $\delta^{18} \mathrm{O}-\mathrm{Mg} / \mathrm{Ca}$ based sea-level estimate with the backstripped estimates from VA, Enewetak, and New Zealand illustrate general agreement and indicate peak values indicative of some loss of the EAIS, but again with large error estimates (Fig. 2). Given the errors in the various analyses (e.g. up to \pm 15 m; Fig. 2) it could be argued that any agreement in amplitude is entirely serendipitous. Despite the limitations of these methods at present, it is extremely likely ( $>95 \%$ probability) that maximum Pliocene sea levels were higher than modern, and very likely higher (>90\% probability) than the last interglacial (8 $\pm 2 \mathrm{~m}$; Dutton et al. 2015) during the peak highstands of the Pliocene warm period.

\section{Summary and future work}

Studies of continental margin and deep-sea sediments have increased age resolution and provided improved constraints on the amplitude of sea-level changes. However, our sea-level estimates have large uncertainties ( \pm 10 to $\pm 15 \mathrm{~m}$ ), thus precluding a definitive statement regarding EAIS melt during the Pliocene. For example, the estimate of $22 \pm 10 \mathrm{~m}$ could allow melting between 0 and $40 \%$ of the EAIS (Miller et al. 2012). The Site $846 \delta^{18} \mathrm{O}_{\text {benthic }}$ record places constraints likely excluding values above $20 \mathrm{~m}$. Our best estimate of approximately $12-20 \mathrm{~m}$ is consistent with melting of the EAIS in the Wilkes and Aurora sub-basins suggested by models (DeConto and Pollard 2003) and sediment tracer data (e.g. Bertram et al. 2018). Future studies would benefit from improved modeling of the effects of MDT, improved understanding of evolution ocean $\mathrm{Mg} / \mathrm{Ca}$ and diagenesis, and key observations around Antarctica by ocean/ice drilling to pinpoint active and decaying ice sectors through time.

\section{AFFILIATIONS}

'Department of Earth and Planetary Sciences and Rutgers Institute of Earth, Ocean, and Atmospheric Sciences, The State University of New Jersey, New Brunswick, USA

${ }^{2}$ Lamont Doherty Earth Observatory and Department of Earth and Environmental Science, Columbia University, Palisades, NY, USA

\section{CONTACT}

Kenneth G. Miller: kgm@rutgers.edu

\section{REFERENCES}

Bartoli G et al. (2011) Paleoceanography 26: PA4213 Bertram R et al. (2018) Earth Planet Sci Lett 494: 109-116 Cramer B et al. (2011) J Geophys Res 116: C12023 DeConto R, Pollard D (2003) Palaeogeogr, Palaeoclimatol, Palaeoecol 198: 39-52

\section{Dowsett H et al. (2013) Sci Rep 3: 2013}

Dutton A et al. (2015) Science 349: aaa4019

Hayden T et al. (2008) Geology 36: 327-330 Kominz M et al. (2016) Geosphere 12: 1437-1456 Lisiecki L, Raymo M (2005) Paleoceanography 20: PA1003 Miller K et al. (2005) Science 310: 1293-1298 Miller K et al. (2011) Oceanography 24: 40-53 Miller K et al. (2012) Geology 40: 407-410 Raymo M et al. (2009) PAGES News 17: 58-59 Raymo M et al. (2011) Nat Geosci 4: 328-332 Raymo M et al. (2018) Earth-Sci Rev 177: 291-302 Rovere A et al. (2014) Earth Planet Sci Lett 387: 27-33 Rowley D et al. (2013) Science 340: 1560-1563 Winnick M, Caves J (2015) Geology 43: 879-882 Woodard S et al. (2014) Science 346: 847-851 